J. Dairy Sci. 98:2183-2196

http://dx.doi.org/10.3168/jds.2014-8807

(C) American Dairy Science Association ${ }^{\circledR}, 2015$.

\title{
Effects of dairy system, herd within dairy system, and individual cow characteristics on the volatile organic compound profile of ripened model cheeses
}

\author{
M. Bergamaschi, ${ }^{\dagger} \dagger$ E. Aprea, ${ }^{*}$ E. Betta, ${ }^{*}$ F. Biasioli, ${ }^{*}$ C. Cipolat-Gotet, $†$ A. Cecchinato, $\dagger$ G. Bittante, $\dagger$ \\ and F. Gasperi*1 \\ *Department of Food Quality and Nutrition, Research and Innovation Centre, Fondazione Edmund Mach (FEM) Via E. Mach 1, \\ 38010 San Michele all'Adige (TN), Italy \\ †Department of Agronomy, Food, Natural Resources, Animals and Environment (DAFNAE), University of Padova, Viale dell'Università 16, \\ 35020 Legnaro (PD), Italy
}

\begin{abstract}
The objective of this work was to study the effect of dairy system, herd within dairy system, and characteristics of individual cows (parity, days in milk, and daily milk yield) on the volatile organic compound profile of model cheeses produced under controlled conditions from the milk of individual cows of the Brown Swiss breed. One hundred fifty model cheeses were selected from 1,272 produced for a wider study of the phenotypic and genetic variability of Brown Swiss cows. In our study, we selected 30 herds representing 5 different dairy systems. The cows sampled presented different milk yields (12.3-43.2 kg/d), stages of lactation (10-412 $\mathrm{d}$ in milk), and parity (1-7). In total, 55 volatile compounds were detected by solid-phase microextraction and gas chromatography-mass spectrometry, including 14 alcohols, 13 esters, 11 free fatty acids, 8 ketones, 4 aldehydes, 3 lactones, 1 terpene, and 1 pyrazine. The most important sources of variation in the volatile organic profiles of model cheeses were dairy system (18 compounds) and days in milk (10 compounds), followed by parity ( 3 compounds) and milk yield ( 5 compounds). The model cheeses produced from the milk of tied cows reared on traditional farms had lower quantities of 3-methyl-butan-1-ol, 6-pentyloxan-2-one, 2-phenylethanol, and dihydrofuran-2(3H)-one compared with those reared in freestalls on modern farms. Of these, milk from farms using total mixed rations had higher contents of alcohols (hexan-1-ol, octan-1-ol) and esters (ethyl butanoate, ethyl pentanoate, ethyl hexanoate, and ethyl octanoate) and lower contents of acetic acid compared with those using separate feeds. Moreover, dairy systems that added silage to the total mixed ration produced cheeses with lower levels of volatile
\end{abstract}

Received September 1, 2014.

Accepted December 27, 2014.

${ }^{1}$ Corresponding author: flavia.gasperi@fmach.it organic compounds, in particular alcohols (butan-1-ol, pentan-1-ol, heptan-1-ol), compared with those that did not. The amounts of butan-2-ol, butanoic acid, ethyl-2-methylpropanoate, ethyl-3-methylbutanoate, and 6-propyloxan-2-one increased linearly during lactation, whereas octan-1-ol, 3-methyl-3-buten-1-ol, 2-butoxyethanol, 6-pentyloxan-2-one, and 2,6-dimethylpyrazine showed a more complex pattern during lactation. The effect of the number of lactations (parity) was significant for octan-1-ol, butanoic acid, and heptanoic acid. Finally, concentrations of octan-1-ol, 2-phenylethanol, pentanoic acid, and heptanoic acid increased with increasing daily milk yield, whereas dihydrofuran$2(3 \mathrm{H})$-one decreased. In conclusion, the volatile organic compound profile of model cheeses from the milk of individual cows was affected by dairy farming system and stage of lactation and, to lesser extent, by parity and daily milk yield.

Key words: cheese quality, lactation stage, milk yield, solid-phase microextraction/gas chromatography-mass spectrometry (SPME/GC-MS), aroma

\section{INTRODUCTION}

Dairy products are deemed acceptable by consumers mainly on the basis of their sensory qualities, with flavor playing a major role (Liggett et al., 2008; Liaw et al., 2010; Bittante et al., 2011b). Cheese flavor is determined by volatile and nonvolatile compounds generated from milk fat, protein, and lactose during the ripening process (Marilley and Casey, 2004; Drake et al., 2010; Le Quéré, 2011). Discovery of the origins of these molecules can provide information on both the raw materials and the processes used to produce the cheeses (Izco and Torre, 2000). Volatile organic compounds (VOC) in particular are of utmost importance in uncovering the relationships between production chain and consumer acceptability ratings (Fox et al., 2004). Perceived odors or flavors are the result of a 
mixture of odorants, and individual components may lose their specific identity when combined with others to produce a new mixture-specific aroma (Le Berre et al., 2008). Therefore, although identification of the quality attributes of individual volatile compounds may be related to the flavor of the product, the interactions between several compounds must also be taken into account (Aprea et al., 2012).

The sensory properties of cheese are affected by several genetic, environmental, and technological factors (Bittante et al., 2011b), and consumers are increasingly concerned, in particular, by those relating to the feeding, breeding, and health of animals. The chemical composition of milk, and consequently of cheese, is affected by several factors, such as dairy cow management, season, genetics, diet, parity, and stage of lactation (Coulon et al., 2004; Coppa et al., 2011). It is essential to quantify the relative importance of the different factors influencing cheese production, in particular those relating to milk production conditions, to be able to better predict and manage cheese quality (Bittante at al., 2011a). Although the effects of farming methods and diet on milk and cheese composition have been studied (Romanzin et al., 2013; Bovolenta et al., 2014), few studies have examined the relationships between variations in $\mathrm{VOC}$ of cheese and variations among individual animals. Understanding the possible effects of environmental, management, and individual cow factors on the characteristics of milk that could in turn affect the quality of cheese is essential (Barbano and Lynch, 2006), especially where Protected Designation of Origin (PDO) cheeses produced according to traditional techniques are concerned. Interesting and fundamental insights as well as practical indications can be gained by an approach that accounts for the entire production chain; that is, by studying the relationships between the characteristics of milk produced on different farms and from individual animals and the sensory characteristics of ripened cheese, in particular the VOC profile.

The development of model cheese-making procedures suitable for application to large numbers of individual samples (Cipolat-Gotet et al., 2013) offers a new tool for research in this field. Model cheeses appear suitable for studying the effects of herd-test date, lactation stage, parity, and milk yield of cows on percentage cheese yields (fresh curd, curd solids, and water retained in the curd as fractions of milk processed), daily cheese yields (expressed per cow per day of lactation), and nutrient recovery or whey loss (weight of protein, fat, total solids, or energy retained in the curd as a percentage of the same nutrient in the processed milk). These data could also be used for genetic analysis, because all cheese yield and recovery traits are characterized by heritability coefficients equal to or greater than those of milk yield and composition (Bittante et al., 2013). Individual model cheesemaking is not feasible at the population level, but infrared (Fourier-transform infrared, FTIR) calibrations have been shown to be a feasible means to predict cheese yield traits from unprocessed milk samples collected for milk recording (Ferragina et al., 2013). This is because the predicted new phenotypes are characterized by heritability coefficients similar to those of the corresponding measured traits and the genetic correlations between the 2 are high (Bittante et al., 2014). The FTIR predictions can be used on dairy cows of different breeds at the population level (Cecchinato et al., 2015).

If model cheesemaking technology has allowed new insights to be gained, it is important to assess the feasibility of using it to improve our knowledge of the factors affecting cheese quality, especially flavor. Volatile organic compounds are generally analyzed by GC-MS, and solid-phase microextraction (SPME) is used to collect and concentrate the compounds present in the headspace from matrices in both solid and liquid states. This method is simple and rapid, uses a sample preparation method free from organic solvents, and has good resolution, high sensitivity, and low cost, which is why SPME is now commonly used in food analysis as well as in cheese volatile compound analysis (Tunick et al., 2013; Padilla et al., 2014).

A large research project has been set up with the aim of studying relationships between individual cow characteristics and herd environment and management. The present study is intended to contribute to our understanding of the factors affecting cheese volatile compounds potentially contributing to cheese flavor by investigating the effects of the dairy system, herds within the dairy system, and the characteristics of individual cows (DIM, parity, milk yield) on the VOC profiles of individual model cheeses.

\section{MATERIALS AND METHODS}

\section{Animals and Milk Sampling}

This study is part of the "Cowplus Project," supported by the Province of Trento, the objectives of which were to investigate the relationships between dairy cows and cheese quality traits and to assess the potential for genetic improvement of the dairy cattle population. The sampling procedure used in the project has been described in detail by Cipolat-Gotet et al. (2012) and Cecchinato et al. (2013), and the production environment is described in Sturaro et al. (2013). Individual milk samples were obtained from 1,272 Brown Swiss cows from 85 herds located in Trento province, 
Table 1. Main features characterizing the mountain dairy systems ${ }^{1}$ sampled

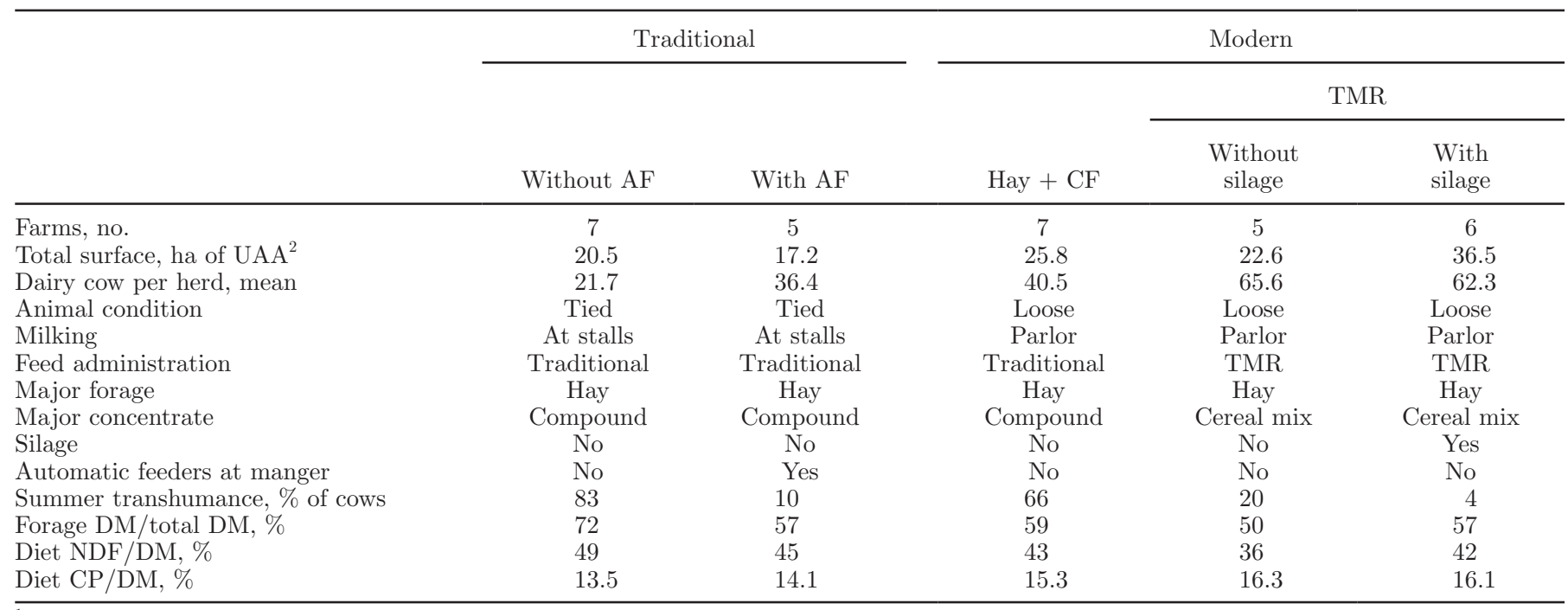

${ }^{1} \mathrm{AF}=$ automatic feeders at mangers to control individually concentrate distribution; $\mathrm{CF}=$ compound feed distributed at mangers; without silage $=$ water added in the mixer wagon to enhance mixing.

${ }^{2} \mathrm{UAA}=$ utilized agricultural area.

an Alpine area in northeastern Italy. In the present work, we analyzed a subset of 150 milk samples from 30 herds ( 5 cows from each herd) representing 5 different dairy systems, whose main features are summarized in Table 1.

The dairy systems in the Alpine area investigated, as in many other mountainous areas, vary considerably in terms of available facilities, technologies adopted, relationships with the environment, numbers and breeds of cows reared, animal welfare and productivity, and milk quality and destination (Sturaro et al., 2009). Following research on the entire province of Trento aimed at clustering and characterizing the different dairy systems (Sturaro et al., 2013), the present study examined 5 dairy systems clustered mainly according type of facilities available and management practices. They ranged from the very traditional system typical of the Alps to the more modern type very common on the plains (Table 1). The first (traditional) system is based on small, old barns with tied animals milked at the stall, calving concentrated mainly in autumn, and cows and heifers moving to highland pastures (summer transhumance). The second (modern) system is based on larger, modern facilities, loose animals, milking parlors, year-round calving and TMR feeding, including (with silage) or excluding (without silage) maize silage. A variant of the traditional system abandons seasonal organization and summer transhumance for lactating cows and adopts automatic distribution of compound feed at the manger, whereas an intermediate dairy system has modern facilities but a traditional feeding of hay and concentrates.
In the Alps, different dairy systems are often associated with different breeds of cattle, with Holstein Friesians prevalent in intensive modern farms; local and dual-purpose breeds in traditional farms; and Brown Swiss cows reared in a range of dairy systems (Sturaro et al., 2013). The present study investigated only Brown Swiss cows to avoid confounding differences between dairy systems with different breeds.

The cows sampled differed in their daily milk yields $(12.3-43.2 \mathrm{~kg} / \mathrm{d})$, stages of lactation (10-412 DIM), and parity (1-7). Collection, refrigeration, transport, and storage of milk samples were standardized to minimize differences among herds and dates. After collection, milk samples (without preservative) were immediately refrigerated at $4^{\circ} \mathrm{C}$ and processed within 20 $\mathrm{h}$ at the cheese-making laboratory of the Department of Agronomy, Food, Natural Resources, Animals and Environment (DAFNAE) of the University of Padova (Padova, Italy) for fat, protein, and casein percentages using a MilkoScan FT6000 apparatus (Foss Electric A/S, Hillerød, Denmark), for $\mathrm{pH}$ using a Crison Basic 25 electrode (Crison, Barcelona, Spain), and for cheesemaking.

\section{Model Cheeses}

Model cheeses were manufactured from the raw milk of individual cows according to the method described by Cipolat-Gotet et al. (2013). Briefly, 1,500 mL of milk was heated to $35^{\circ} \mathrm{C}$ in a stainless steel microvat, supplemented with thermophilic starter culture, and mixed with rennet. The resulting curd was cut, 
drained, shaped in wheels, pressed, salted, and weighed $(225 \pm 29 \mathrm{~g})$. The small wheels produced were ripened at $15^{\circ} \mathrm{C}$ and $85 \%$ relative humidity for the first month and at $12^{\circ} \mathrm{C}$ and the same relative humidity for the second month. After $60 \mathrm{~d}$, the model cheeses were weighed $(133 \pm 18 \mathrm{~g})$ and analyzed (Table 2$)$. The fat and protein contents of the whole cheeses, after removal of the rind, were measured using a FoodScan apparatus (Foss Electric A/S). The $\mathrm{pH}$ was measured at $20^{\circ} \mathrm{C}$ by inserting a Basic 20 electrode (Crison) into each model cheese. A cylindrical sample, $1.1 \mathrm{~cm}$ in diameter and about $3.5 \mathrm{~cm}$ in height, was taken from the center of each model cheese and conserved at $-80^{\circ} \mathrm{C}$ until VOC analysis.

\section{VOC Analysis by SPME and GC-MS}

Headspace SPME coupled with GC-MS was conducted using a modified version of the method reported in Endrizzi et al. (2012). The cheese samples were thawed and kept at room temperature (about $20^{\circ} \mathrm{C}$ ) for $6 \mathrm{~h}$; then, $3 \mathrm{~g}$ from each sample was placed into glass vials (20 mL, Supelco, Bellefonte, PA) and gently mashed with a spatula. The vials were then capped with a polytetrafluoroethylene-silicone septum (Supelco) and the samples equilibrated at $40^{\circ} \mathrm{C}$ for $30 \mathrm{~min}$. A fused-silica fiber coated with $50 / 30 \mu \mathrm{m}$ divinylbenzene/carboxen/polydimethylsiloxane

(DBV/CAR/
PDMS, Supelco) was then inserted and exposed to the headspace environment for $30 \mathrm{~min}$ at the same temperature. Volatile compounds absorbed by the SPME fiber were desorbed at $250^{\circ} \mathrm{C}$ in the injector port of a GC interfaced with a mass detector operating in an electron ionization mode (internal ionization source; 70 $\mathrm{eV}$ ) with a scan range of $\mathrm{m} / z 33$ to 300 (GC Clarus 500, PerkinElmer, Norwalk, CT). Procedure phases were automatically managed using an auto-sampling system (CTC combiPAL, CTC Analysis AG, Zwingen, Switzerland). Separation was carried out on an HPInnowax fused-silica capillary column $(30 \mathrm{~m}, 0.32 \mathrm{~mm}$ i.d., $0.5 \mu \mathrm{m}$ film thickness; Agilent Technologies, Palo Alto, CA). Separation conditions were as follows: carrier gas was helium at a constant flow rate of $2 \mathrm{~mL} /$ min; oven temperature programming was $40^{\circ} \mathrm{C}$ for 3 $\min , 40$ to $180^{\circ} \mathrm{C}$ at $4^{\circ} \mathrm{C} / \mathrm{min}, 180^{\circ} \mathrm{C}$ for $6 \mathrm{~min}$, and finally 180 to $220^{\circ} \mathrm{C}$ at $5^{\circ} \mathrm{C} / \mathrm{min}$. The samples (around 13 per day) were analyzed over $12 \mathrm{~d}$ (date of analysis) in random order. To test the repeatability of the method, 10 replicates of a reference cheese were analyzed on the same day. The observed averaged variations were $23,14,8,13$, and $20 \%$, respectively, for acids, alcohols, esters, ketones, and aldehydes, in agreement with the literature for SPME analysis with this type of matrix (Mallia et al., 2005; Endrizzi et al., 2012) and with other types of food (San Román et al., 2014). Levels of VOC in the samples were expressed as fractions of the total chromatography area.

Table 2. Descriptive statistics of milk yield and milk and cheese composition traits of sampled cows according to different dairy systems ${ }^{1}$ (mean $\pm \mathrm{SD}$ )

\begin{tabular}{|c|c|c|c|c|c|}
\hline \multirow[b]{3}{*}{ Item } & \multicolumn{2}{|c|}{ Traditional (tied, hay $+\mathrm{CF}$ ) } & \multicolumn{3}{|c|}{$\begin{array}{c}\text { Modern } \\
\text { (pens with free animals and milking parlor) }\end{array}$} \\
\hline & \multirow[b]{2}{*}{ Without AF } & \multirow[b]{2}{*}{ With AF } & \multirow[b]{2}{*}{ Hay + CF } & \multicolumn{2}{|c|}{ TMR } \\
\hline & & & & Without silage & With silage \\
\hline Sampled cows, no. & 35 & 25 & 35 & 25 & 30 \\
\hline Milk yield, $\mathrm{kg} / \mathrm{d}$ & $19.1( \pm 6.3)$ & $23.5( \pm 8.4)$ & $25.1( \pm 7.4)$ & $30.2( \pm 9.7)$ & $26.8( \pm 6.9)$ \\
\hline DIM, d & $156( \pm 101)$ & $167( \pm 112)$ & $158( \pm 95)$ & $169( \pm 100)$ & $163( \pm 103)$ \\
\hline Parity & $2.5( \pm 1.1)$ & $2.4( \pm 1.1)$ & $2.3( \pm 1.0)$ & $2.1( \pm 1.0)$ & $2.4( \pm 0.9)$ \\
\hline \multicolumn{6}{|l|}{ Milk composition } \\
\hline Fat, \% & $4.2( \pm 0.6)$ & $4.3( \pm 1.3)$ & $4.1( \pm 0.9)$ & $4.5( \pm 1.1)$ & $4.7( \pm 0.9)$ \\
\hline Protein, $\%$ & $3.6( \pm 0.4)$ & $3.6( \pm 0.6)$ & $3.7( \pm 0.4)$ & $3.8( \pm 0.5)$ & $3.8( \pm 0.4)$ \\
\hline Casein, \% & $2.8( \pm 0.3)$ & $2.8( \pm 0.4)$ & $2.9( \pm 0.3)$ & $3.0( \pm 0.4)$ & $2.9( \pm 0.3)$ \\
\hline Fat:protein & $1.20( \pm 0.18)$ & $1.22( \pm 0.46)$ & $1.10( \pm 0.28)$ & $1.17( \pm 0.16)$ & $1.25( \pm 0.33)$ \\
\hline $\mathrm{SCS}^{2}$ & $2.31( \pm 1.81)$ & $3.31( \pm 2.41)$ & $3.16( \pm 1.54)$ & $3.17( \pm 1.60)$ & $3.51( \pm 1.97)$ \\
\hline $\mathrm{pH}$ & $6.64( \pm 0.09)$ & $6.63( \pm 0.08)$ & $6.65( \pm 0.08)$ & $6.64( \pm 0.06)$ & $6.61( \pm 0.08)$ \\
\hline \multicolumn{6}{|l|}{ Cheese composition } \\
\hline Fat, $\%$ & $38.6( \pm 4.7)$ & $37.2( \pm 4.6)$ & $36.7( \pm 3.9)$ & $39.3( \pm 4.4)$ & $41.0( \pm 6.0)$ \\
\hline Fat in DM, \% & $48.0( \pm 4.1)$ & $45.4( \pm 4.0)$ & $46.1( \pm 4.9)$ & $48.6( \pm 4.0)$ & $50.5( \pm 6.6)$ \\
\hline Protein, $\%$ & $26.8( \pm 4.4)$ & $26.0( \pm 4.8)$ & $28.9( \pm 4.1)$ & $26.9( \pm 3.8)$ & $25.0( \pm 4.5)$ \\
\hline TS, \% & $80.3( \pm 4.8)$ & $81.9( \pm 5.5)$ & $79.8( \pm 4.7)$ & $80.9( \pm 3.8)$ & $81.2( \pm 4.0)$ \\
\hline $\mathrm{pH}$ & $5.17( \pm 0.23)$ & $5.17( \pm 0.12)$ & $5.17( \pm 0.21)$ & $5.12( \pm 0.11)$ & $5.25( \pm 0.17)$ \\
\hline
\end{tabular}

${ }^{1} \mathrm{AF}=$ automatic feeders at mangers to control individually concentrate distribution; $\mathrm{CF}=$ compound feed distributed at mangers; without silage $=$ water added in the mixer wagon to enhance mixing.

${ }^{2} \mathrm{SCS}=\log _{2}(\mathrm{SCC} / 100,000)+3$. 


\section{Statistical Analysis}

Given that the distribution of all VOC showed a strong positive skewness, data transformation was applied: the fraction of each VOC was multiplied by $10^{6}$ and expressed as a natural logarithm to obtain a more Gaussian-like data distribution before statistical analysis, as is shown by the skewness and kurtosis coefficient reported in Table 3. All transformed data that were 3 standard deviations or more outside the mean were considered outliers and excluded from the statistical analysis. The data set was analyzed using the MIXED procedure of SAS (SAS Inst. Inc., Cary, NC) according to the following model:

$$
\begin{aligned}
& \mathrm{Y}_{\mathrm{ijklmnopq}}=\mu+\text { dairy } \text { system }_{\mathrm{i}}+\mathrm{HTD}_{\mathrm{j}}(\text { dairy system })_{\mathrm{i}} \\
& +\mathrm{DIM}_{\mathrm{k}}+\text { parity }_{\mathrm{l}}+\text { milk }_{\mathrm{m}}+\text { vat }_{\mathrm{n}} \\
& + \text { date }_{\mathrm{o}}+\mathrm{inj}_{\mathrm{p}}+\mathrm{e}_{\mathrm{ijk} \mathrm{kmnopq}}
\end{aligned}
$$

where $\mathrm{y}_{\mathrm{ijklmnopq}}$ is the observed trait $(55 \mathrm{VOC}$ and their 6 chemical families); $\mu$ is the overall mean; dairy system $_{\mathrm{i}}$ is the fixed effect of the $i$ th dairy system $(\mathrm{i}=1$ to $5) ; \operatorname{HTD}_{\mathrm{j}}(\text { dairy system })_{\mathrm{i}}$ is the random effect of the $j$ th herd/test date (HTD; $\mathrm{j}=1$ to 30 ) within $i$ th dairy system; $\mathrm{DIM}_{\mathrm{k}}$ (interval from parturition to milk sampling) is the fixed effect of the $k$ th class of days in milk $(\mathrm{k}=$ 1 to 7 , class 1: $\leq 50 \mathrm{~d}$, class 2: 51 to $100 \mathrm{~d}$, class 3: 101 to 150 d, class 4: 151 to 200 d, class 5: 201 to 250 d, class 6: 251 to 300 , class 7: $>300 \mathrm{~d}$ ); parity $_{1}$ (number of parturitions) is the fixed effect of the lth parturition (1 $=1$ to 4 or more); milk $\mathrm{m}_{\mathrm{m}}$ (daily milk yield, $\mathrm{kg} / \mathrm{d}$ ) is the linear covariate of milk yield; vat $_{n}$ is the fixed effect of the $n$th number of the experimental vat used for model cheese production ( $\mathrm{n}=1$ to 15$)$; date $_{\mathrm{o}}$ is the fixed effect of the oth day of SPME/GC-MS analysis $(o=1$ to 12$) ;$ inj $_{\mathrm{p}}$ is the fixed effect of the $p$ th daily injection order into the instrument $(P=1$ to 12$)$; $\mathrm{e}_{\mathrm{ijk} k m n o p}$ is the residual random error term $\sim \mathrm{N}\left(0, \sigma^{2}\right)$. Dairy system effect was tested using HTD within dairy system as the error term, whereas other fixed effects were tested on the residual. Orthogonal contrasts were used to test the effects of dairy system and parity.

\section{RESULTS AND DISCUSSION}

\section{VOC Profiles of Individual Model Cheeses}

The quality traits of milk and model cheeses are reported in Table 2. Average milk yields and fat, protein, and casein contents were $24.6 \mathrm{~kg} / \mathrm{d}$, and $4.3,3.7$, and $2.9 \%$, respectively. Average fat and protein contents of these cheeses at $60 \mathrm{~d}$ of ripening were 38.6 and $26.8 \%$, respectively. Milk yield showed the largest coefficient of variation and $\mathrm{pH}$ the smallest for both milk and cheese.

The 55 VOC identified in the model cheeses belong to the following chemical families: 14 alcohols from $\mathrm{C}_{4}$ to $\mathrm{C}_{8} ; 13$ esters from $\mathrm{C}_{4}$ to $\mathrm{C}_{12}$, mainly ethyl esters; 11 FFA from $\mathrm{C}_{2}$ to $\mathrm{C}_{10} ; 8$ methyl ketones from $\mathrm{C}_{4}$ to $\mathrm{C}_{11}$; 4 aldehydes from $\mathrm{C}_{5}$ to $\mathrm{C}_{9} ; 3$ lactones from $\mathrm{C}_{4}$ to $\mathrm{C}_{10} ; 1$ terpene; 1 pyrazine. All VOC peak areas showed a nonGaussian right-skewed distribution. The mean values of the natural logarithms of the peak area of the 55 VOC along with their 6 summed values according to their chemical family are shown in Table 3 , together with their skewness and kurtosis coefficients, showing the almost-Gaussian distribution achieved after transformation. The VOC related to both flavor (by retronasal perception) and odor (direct orthonasal perception), although it is known that these sensory quality traits are the result of a mixture of compounds, with the single components frequently losing their individual identity and a new mixture-specific odor quality emerging. Thus, the identification of the quality attribute of a single volatile compound is only indicative (Le Berre et al., 2008).

Odor-active compounds are usually identified by GC-olfactometry, although this method cannot take into account the interactions between the compounds, nor their enhancement or fusion because the individual compounds are evaluated only after having been separated. To understand food aroma as perceived by the consumer, sensory characterization of the global aroma of the food product is also necessary (Drake, 2007; Cornu et al., 2009; Thomsen et al., 2012).

All VOC displayed low to medium variability, with the coefficient of variation ranging from $3 \%$ for butanoic acid to $30 \%$ for 2-ethylhexanoic acid. However, the variability coefficients of VOC summed by chemical family were much lower than those of individual VOC (from 1\% for FFA to $8 \%$ for aldehydes) because of compensating patterns among the amounts of individual VOC within the same family. With respect to the low coefficients of variability, it should be remembered that the concentrations are expressed in logarithmic terms; in linear untransformed terms, the variability is much greater and the distribution positively skewed. The volatile compound profile of model cheeses displayed a marked variability, probably also because of variability in the native microflora of raw milk from different herds and cows (Urbach, 1995; Urgeghe et al., 2012). After transformation into natural logarithms, the values of skewness and kurtosis of the peak area normalized to the total chromatography area were close to zero, suggesting that they were almost normally distributed (Table 3). The effect of date of analysis was significant only for esters and the family of other 
Table 3. Descriptive statistics of volatile organic compounds (VOC) detected by solid-phase microextraction and GC-MS on ripened individual model cheeses

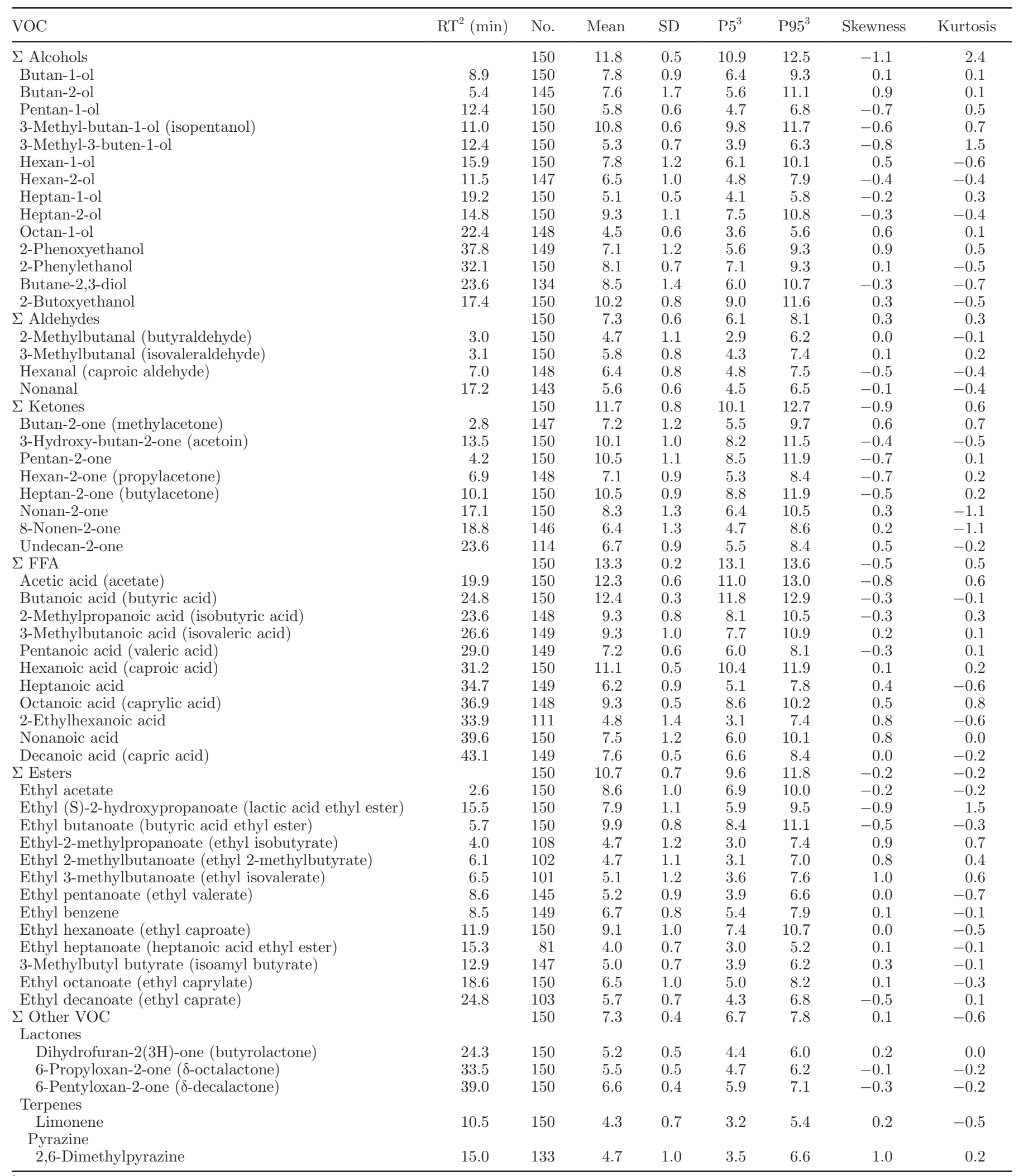

${ }^{1}$ Expressed as natural logarithm of peak area normalized to total chromatography area.

${ }^{2} \mathrm{RT}=$ retention time.

${ }^{3} \mathrm{P} 5$ and $\mathrm{P} 95=5$ th and 95 th percentiles. 
Table 4. Effects of dairy system and incidence of herd/test date within dairy system (HTD), and effects of DIM, parity, milk yield, vat, date of analysis (date), and order of injection (inj) on the sums of volatile organic compounds (VOC) by chemical family variance on total variance

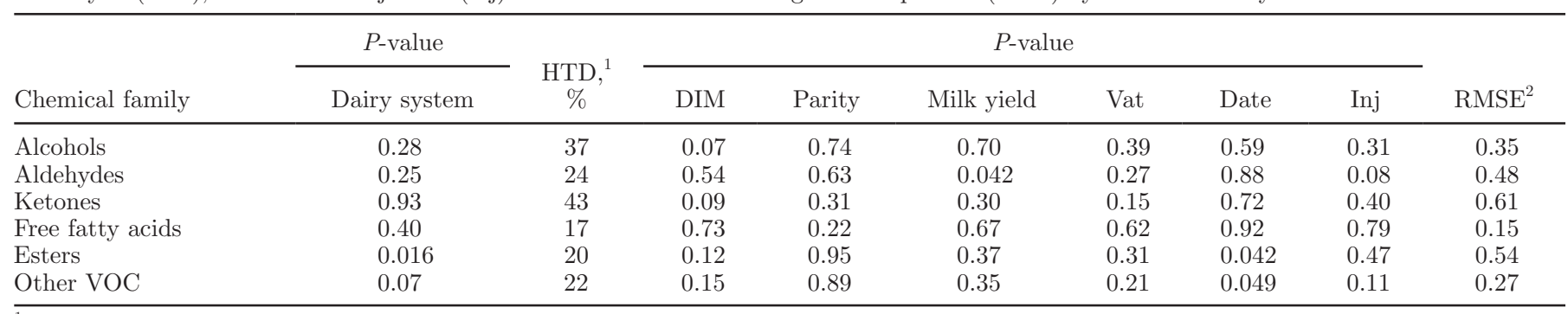

${ }^{1}$ HTD effect expressed as proportion of variance explained by herd/test date calculated by dividing the corresponding variance component by the total variance.

${ }^{2} \mathrm{RMSE}=$ root mean square error.

VOC, confirming good reproducibility of the technique adopted. The 4 esters affected by date of analysis were ethyl-2-methylpropanoate, ethyl benzene, ethyl octanoate, and ethyl decanoate, which increased significantly $(P<0.05)$ over the course of the analysis period, whereas dihydrofuran-2(3H)-one, 6-pentyloxan-2-one, and limonene (other VOC) decreased significantly $(P$ $<0.001$ ) from the first to last day of analysis (data not shown). Effects of vat and order of injection were not significant for any of the chemical VOC families analyzed, confirming acceptable reproducibility of the procedure (Table 4). The predominant chemical family of compounds identified was FFA (average ln of 13.3, corresponding to a linear value of almost $60.0 \%$ ). Alcohols (mean value of $\ln 11.8$, equal to $13.3 \%$ ), ketones (ln of 11.7 , equal to $12.0 \%$ ) and esters (ln of 10.7 , equal to $4.4 \%$ ) were found in intermediate amount, whereas aldehydes and other VOC (both with $\ln$ of 7.3 , equal to $0.1 \%$ ) were represented to a much lesser extent. Both primary and secondary alcohols were found. The primary alcohols were butan-1-ol, pentan-1-ol, hexan-1-ol, heptan-1-ol, and octan-1-ol, which may originate from the corresponding aldehydes produced from FA and AA metabolism (Barbieri et al., 1994). They can contribute fruity, green notes to the flavor of cheese (Curioni and Bosset, 2002). The secondary alcohols were butan-2-ol, hexan-2-ol, and heptan-2-ol, which have also been reported in Parmigiano-Reggiano, Roquefort, and Cheddar cheeses (Engels et al. 1997). They are important flavor components of blue cheeses, where they are produced through reduction of methyl ketones (Curioni and Bosset, 2002). Butan-2-ol may be formed by reduction of butan-2,3-dione (diacetyl) to butane-2,3-diol by starter bacteria, and subsequent reduction to butan-2-ol by activity of nonstarter lactic acid bacteria during cheese ripening (Berard et al., 2007). The most abundant alcohol (taking into account the peak area) detected in all the cheese chromatograms was 3-methyl-butan-1-ol, which is formed by reduction of aldehydes or by Strecker degradation of leucine. This is the main volatile aromatic compound produced during cheese ripening and is observed in many types of cheeses. Similar results have been observed in other raw milk cheeses, where this alcohol has been found in high amounts (Carbonell et al., 2002; Berard et al., 2007).

The branched-chain aldehydes 2-methylbutanal and 3-methylbutanal, likely derived from lipid oxidation, were detected in all the cheeses analyzed (Table 3 ). These aldehydes are often associated with malty and herbaceous flavors (Cornu et al., 2009). Aldehydes may also derive from AA during ripening (Strecker degradation) and, in some cheeses, they are considered the key flavor compounds (Curioni and Bosset, 2002). Liaw et al. (2010) suggested that these compounds are responsible for off-flavors in dairy products and they increase in quantity with storage or processing time. The aldehyde content in cheese is limited by redox potential, unsaturated FA content, and lipolysis activity (Engels et al., 1997; Ziino et al., 2005; Berard et al., 2007).

The most abundant ketones found in all samples (in similar average quantities) were pentan-2-one, heptan-2 one, and 3-hydroxy-butan-2-one (Table 3). Methyl ketones are naturally present in dairy products (Curioni and Bosset, 2002) and can also be formed by enzymatic oxidation of FA to $\beta$-ketoacids with consequent decarboxylation to alkan-2-ones with the loss of one carbon atom (McSweeney and Sousa, 2000), whereas 3-hydroxy-butan-2-one is formed through glycolysis from pyruvic acid (Marilley and Casey, 2004). High amounts of pentan-2-one and heptan-2-one are present in the volatile fraction of Parmigiano-Reggiano cheese (Barbieri et al., 1994; Bellesia et al., 2003). Pentan2-one and heptan-2-one have fruity, herbaceous flavors, characteristics of Swiss Gruyère and Camembert cheeses (Izco and Torre, 2000), whereas 3-hydroxy-butan-2-one presents a buttery aroma (Cornu et al., 2009).

Among the esters, ethyl butanoate had the greatest area value, followed by ethyl hexanoate and ethyl ac- 
etate. A high content of ethyl butanoate has been found in Parmigiano-Reggiano and Gruyère cheeses (Ziino et al., 2005). Esters are mainly produced by the enzymatic or chemical reaction of FA with alcohol (Curioni and Bosset, 2002), their concentrations usually being the limiting factor in production; they can also be formed by transesterification of partial glycerides (Ziino et al., 2005). Ethyl esters (especially ethyl butanoate and ethyl hexanoate) are considered key odorants in some cheese varieties, such as grana types (Urgeghe et al., 2012), Parmigiano-Reggiano (Barbieri et al., 1994), Canestrato Pugliese, and Provola (Ziino et al., 2005). They have low perception thresholds and may contribute typical floral and fruity notes to cheese aromas (Liu et al., 2004), minimizing the sharpness of FA and the bitterness of amine (Urgeghe et al., 2012).

The most abundant FA were acetic acid, butanoic acid, and hexanoic acids (Table 3). Several authors have observed these acids in different kinds of cheeses, such as pasta filata cheeses (Ziino et al., 2005), Parmigiano-Reggiano (Bellesia et al., 2003), and Swiss Gruyère (Rychlik and Bosset, 2001). Butanoic acid and hexanoic acid (containing 4 or more carbon atoms) are generally produced from lipolysis of milk fat, whereas acetic acid results from oxidation of lactose and catabolism of alanine and serine by lactic acid bacteria (Ziino et al., 2005). Acetic acid gives rise to vinegary notes in cheese, butanoic acid to vomit and feet notes, and hexanoic acid to cheese rind notes (Bendall, 2001; Cornu et al., 2009).

We found a high content of 6-pentyloxan-2-one in the lactone group (Table 3). Biosynthesis of these compounds results from the activity of lipoxygenases or hydratases on unsaturated FA, constituents of milk fat (Ziino et al., 2005). Lactones, also present in bovine milk (Bendall, 2001), provide peach, apricot, and coconut odors in cheese. 6-Pentyloxan-2-one and 6-propyloxan2-one have also been found in Camembert, Emmental, and goat cheese (Curioni and Bosset, 2002).

Terpenes arise from the plants that constituting the animals' diets and are transferred to the milk and then to the cheese. They are important in determining product origin, especially of mountain cheeses, which contain more terpenes than lowland cheeses. These compounds have been listed as odorants in Cheddar and Pecorino cheese because of their fresh, herbaceous odor (Curioni and Bosset, 2002; Acree and Arn, 2004).

McSweeney and Sousa (2000) reported 2,6-dimethylpyrazine in Swiss Gruyère, Parmigiano-Reggiano, and Swiss Emmental cheeses, where it was probably formed by microorganisms; the flavor is that of burnt potato. Other authors note the presence of an earthy odor in British farmhouse Cheddar and Camembert cheese caused by pyrazine (Curioni and Bosset, 2002).

\section{Effects of Dairy System and Herds Within the Dairy System}

Table 2 shows how the dairy system can profoundly affect daily milk yield from the same breed of cow with very similar breeding values. Farms using TMR with or without maize silage produced, on average, 26.8 and $30.2 \mathrm{~kg} / \mathrm{d}$ of milk per cow, respectively, whereas the traditional farms produced only $19.1 \mathrm{~kg} / \mathrm{d}$. Dairy system had a much lower effect on milk composition (fat, protein, and casein contents), with the greatest contents observed for farms using TMR, and on cheese composition. The cow's diet is well known to have a major influence on milk composition but little effect on milk coagulation properties (Bittante et al., 2012); it also influences cheese composition (Lucas et al., 2006). Cheese seems to be more affected by the ratio of fat to protein in milk than by their absolute values, which have a greater effect on cheese yield than on composition (Cipolat-Gotet et al., 2013).

In the present study, we found several differences among the 5 dairy systems with respect to the family of volatile esters (Table 4) and 18 individual VOC (Table 5). It is well documented that dairy systems, in particular feeding practices, affect the sensory properties of cheese (Martin et al., 2004; Tornambé et al., 2005) and its VOC content; this is especially true with pasture-based compared with indoor systems (Cornu et al., 2009; Bovolenta et al., 2014; Farruggia et al., 2014). The effect is particularly pronounced in the case of typical PDO products, where modification of the raw material during processing is restricted or prohibited, and where milk production conditions underlie the notion of "terroir" (Verdier-Metz et al., 2005). In this case, the final quality of the cheese is strictly dependent on the characteristics of the processed milk (Bertoni et al., 2005; Calamari et al., 2005; Endrizzi et al., 2012).

Much less is known about dairy systems that use only dry feedstuffs or silages. To better understand the results of the present study, it is important to note that no permanent dairy system in the province of Trento uses pasture or green fodder administration, and that 4 of the 5 dairy systems studied here did not use silage (Table 1). This is because most of the milk goes to produce Trentingrana cheese, a hard, long-ripened, PDO cheese whose production specification discourages the use of pasture and green fodder and does not allow the use of silage. Although this feeding strategy (hay and compound feed) is often more expensive, it is compensated for by the much higher price paid for the milk by the cooperative dairies producing Trentingrana and other local cheeses (Sturaro et al., 2013) than by producers of conventional dairy products (e.g., fluid milk, yogurt, fresh cheeses). Milk produced from cows grazed 
Table 5. Dairy systems least squares means (LSM) of the quantity of the volatile organic compounds (VOC) with significant orthogonal contrasts

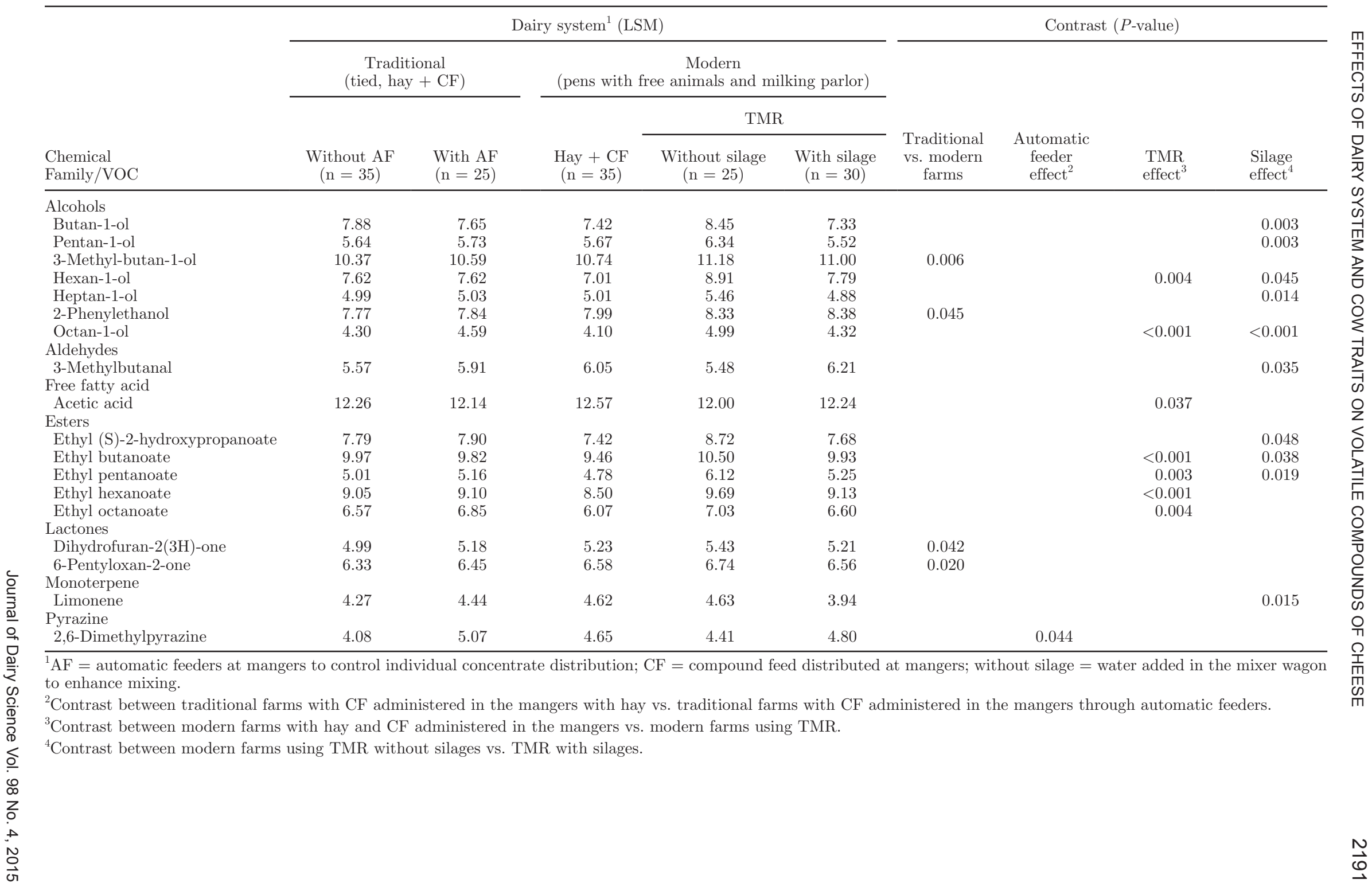


on Alpine pastures during the summer transhumance was not sampled in the present study because it is often used to produce "Malga-type" cheeses directly by farmers (Bovolenta et al., 2009).

Previous studies have drawn attention to variability among the cooperative dairies on the sensory characteristics of high-quality Trentingrana wheels (Bittante et al., 2011a,b), reflecting the differences of the farms supplying the milk (Endrizzi et al., 2013).

Cheeses from modern farms, compared with those from traditional farms, had higher proportions of 3-methylbutan-1-ol and 2-phenylethanol among the alcohols, and of 6-pentyloxan-2-one and dihydrofuran-2(3H)-one among the lactones (Table 5). Of the traditional farms, those distributing compound feed in the mangers with automatic feeders had different 2,6-dimethylpyrazine contents from the others. In modern dairy systems, differences were observed between the VOC profiles of cheeses from farms using hay and compound feed administered in the mangers and those of cheeses from farms using TMR. Use of TMR gave rise to higher contents of 2 primary alcohols, hexan-1-ol and octan-1-ol, and 4 esters, ethyl butanoate, ethyl pentanoate, ethyl hexanoate, and ethyl octanoate. On the other hand, the amount of acetic acid in the headspace of the cheese samples was lower when the milk was from TMR-fed cows than when it was from conventionally fed cows, and this result could be the consequence of different phenomena. As shown in Table 1, farms adopting TMR used greater amount of concentrates, resulting in lower proportions of fiber in diet DM. This often leads to lower concentrations of acetic acid in the rumen. At the same time, milk fat content was increased (Table 2) by TMR use, probably because of increased de novo fat synthesis in the udder from blood acetate.

In dairy systems using TMR, we found greater proportions of the aldehyde 3-methylbutanal, and smaller proportions of primary alcohols butan-1-ol, pentan1-ol, hexan-1-ol, heptan-1-ol, and octan-1-ol, as well as ethyl (S)-2-hydroxypropanoate, ethyl butanoate, ethyl pentanoate, and limonene in systems that added silage than in those that did not (Table 5). Numerous aldehydes are detected in silages, milk, and cheeses (Kalač, 2011). Toso et al. (2002) ascertained that 3-methylbutanal was, by far, the most prevalent aldehyde in milk produced from hay and maize silage rations. The results of the present study are in accordance with previous works that found a higher content of terpenes (such as limonene) in milk and cheese when lactating cows are fed on natural dicotyledon-rich grasses than when fed on monospecific forage or concentrate-based rations (Kalač, 2011). The addition of silage to hay and concentrates fed to lactating dairy cows has been shown to modify the characteristics of the milk (Kalač,
2011) and the ripened cheese (Verdier-Metz et al., 2005) as well as the proportions of VOC both in bulk milk (Toso et al., 2002) and in Montasio cheese (Stefanon and Procida, 2004).

All chemical VOC families were influenced by HTD within dairy system (Table 4), and it is interesting to note that this effect was greater for ketones: the variance of HTD represented $43 \%$ of total variance; for alcohols, it was $37 \%$, and for the other chemical families, it ranged between 17 and $24 \%$. There is little information on the effect of herd in the literature because most articles describe results obtained from statistical analyses with a single experimental herd or several farms as fixed factors.

\section{Effect of DIM}

Of the various factors related to individual cows, stage of lactation appeared to be the most important source of variation in VOC profiles: 10 compounds out of 55 quantified VOC were affected by DIM (Table 6). Butan-2-ol among the alcohols, butanoic acid among FFA, ethyl-2-methylpropanoate and ethyl 3-methylbutanoate among the esters, and 6-pentyloxan-2-one among the lactones exhibited linear increases throughout lactation. The quadratic patterns exhibited by 6-pentyloxan-2-one (lactone) and 2,6-dimethylpyrazine (pyrazine), and the cubic patterns characterizing 3-methyl-3-buten-1-ol, octan-1-ol, 2-butoxyethanol (alcohols), and 6-propyloxan-21 (lactone) were more complex. Given that they are expressed as natural logarithms, the variations in the VOC profiles observed during lactation were much greater than those recorded for milk yield (decrease) and fat and protein contents (increase), although their summed effects could partially explain these variations. Other factors give rise to variations in VOC profiles during lactation, including a change in the quantity and quality of feed ingested (then the rumen environment and fermentation, and the cow's digestion, absorption and metabolism); a change in the cow's energy balance (then fat mobilization or deposition, the ratio of energy to individual nutrients, and the cow's hormonal interactions); pregnancy status (and associated metabolic and physiological changes); modifications to udder secreting tissue (in relation to apoptosis and the secretion of different molecules). Cheeses produced at the end of the animal's lactation have faster proteolysis, especially when the milk SCC contents are high (Coulon et al., 2004), which may influence coagulation properties, cheese yield, and sensory characteristics. Plasmin, the most important proteinase in milk, shows increased activity in late lactation (Coulon et al., 2004). It is also possible that other modifications related to lactation stage, such as increased milk lipolysis or modification of 
Table 6. Days in milk least squares means (LSM) of the quantity of the volatile organic compounds (VOC) with significant orthogonal contrasts

\begin{tabular}{|c|c|c|c|c|c|c|c|c|c|c|}
\hline \multirow[b]{2}{*}{ VOC } & \multicolumn{7}{|c|}{ Days in milk (LSM) } & \multicolumn{3}{|c|}{ Contrast ( $P$-value $)$} \\
\hline & $\begin{array}{c}\leq 50 \\
(\mathrm{n}=20)\end{array}$ & $\begin{array}{c}51-100 \\
(\mathrm{n}=28)\end{array}$ & $\begin{array}{l}101-150 \\
(\mathrm{n}=38)\end{array}$ & $\begin{array}{l}151-200 \\
(\mathrm{n}=15)\end{array}$ & $\begin{array}{l}201-250 \\
(\mathrm{n}=12)\end{array}$ & $\begin{array}{l}251-300 \\
(\mathrm{n}=22)\end{array}$ & $\begin{array}{c}>300 \\
(\mathrm{n}=15)\end{array}$ & Linear & Quadratic & Cubic \\
\hline \multicolumn{11}{|l|}{ Alcohol } \\
\hline Butan-2-ol & 7.01 & 7.30 & 7.39 & 7.14 & 8.44 & 8.31 & 8.42 & \multirow[t]{3}{*}{0.010} & & \\
\hline 3-Methyl-3-buten-1-ol & 5.03 & 5.26 & 5.54 & 5.27 & 5.22 & 5.15 & 5.71 & & & 0.006 \\
\hline Octan-1-ol & 4.66 & 4.29 & 4.46 & 4.44 & 4.45 & 4.72 & 4.20 & & & 0.007 \\
\hline \multicolumn{11}{|l|}{ FFA } \\
\hline Butanoic acid & 12.57 & 12.54 & 12.43 & 12.23 & 12.38 & 12.30 & 12.24 & \multicolumn{3}{|l|}{0.002} \\
\hline \multicolumn{11}{|l|}{ Ester } \\
\hline Ethyl-2-methylpropanoate & 3.95 & 4.20 & 4.48 & 4.56 & 4.44 & 4.37 & 5.50 & \multirow{2}{*}{\multicolumn{2}{|c|}{$\begin{array}{l}0.016 \\
0.020\end{array}$}} & \\
\hline Ethyl-3-methylbutanoate & 4.33 & 4.36 & 4.89 & 5.53 & 4.52 & 5.41 & 5.78 & & & \\
\hline \multicolumn{11}{|l|}{ Lactone } \\
\hline 6-Propyloxan-2-one & 5.50 & 5.56 & 5.67 & 5.54 & 5.21 & 5.18 & 5.24 & \multirow[t]{2}{*}{0.012} & & \multirow[t]{2}{*}{0.039} \\
\hline 6-Pentyloxan-2-one & 6.52 & 6.57 & 6.69 & 6.54 & 6.47 & 6.36 & 6.59 & & 0.021 & \\
\hline
\end{tabular}

fat composition, gave rise to the VOC differences (Coulon et al., 2004). The effect of enzymes on VOC profile cited above could have been more marked in cheeses from milk of late-lactation cows reared in modern dairy systems than traditional systems because the variability of fat in DM (substrates) and SCS were greater (Table 2). The differences observed were also probably due to concomitant variations in feeding practices or the health of the cow (Auldist et al., 1996). Further studies are needed to elucidate the effects of the abovecited factors on milk properties with respect to VOC content and their modification during cheesemaking and ripening.

\section{Effect of Parity}

Parity or age of the cow is an important factor affecting milk yield and quality, although it has only a small effect on milk coagulation properties (Bittante et al., 2012), model cheese yield, or nutrient recovery in curd or loss in whey (Cipolat-Gotet et al., 2013).

Parity did not affect the sum of VOC by chemical family (Table 4) and affected only a few individual VOC in ripened cheeses (Table 7). In particular, parity in the lactating cow influenced the proportions of 1 alcohol and 2 free fatty acids. Cheeses from primiparous cows had a higher content of butanoic acid than the average content in cheeses from older cows. Cheeses from second lactations were found to have a greater proportion of octan-1-ol and a smaller proportion of heptanoic acid than cheeses from later lactations. Finally, among mature cows (3 lactations and more), lower quantities of butanoic acid were observed in the cheeses from older cows (4 or more lactations) than those from younger cows (third lactation). On the other hand, the proportions of butanoic acid and heptanoic acid were found to be lower. However, the differences, although significant, were much smaller than those observed during lactation. There is little information in the literature on the effect of parity in lactating cows on the VOC profiles of cheeses.

\section{Effect of Milk Yield}

The VOC profile of the model cheeses tended to change somewhat with milk yield. We found that only

Table 7. Parity least squares means (LSM) of the quantity of the volatile organic compounds (VOC) with significant orthogonal contrasts

\begin{tabular}{|c|c|c|c|c|c|c|c|}
\hline \multirow[b]{2}{*}{$\begin{array}{l}\text { Chemical } \\
\text { family/VOC }\end{array}$} & \multicolumn{4}{|c|}{ Parity (LSM) } & \multicolumn{3}{|c|}{ Contrast ( $P$-value $)$} \\
\hline & $\begin{array}{c}1 \\
(\mathrm{n}=35)\end{array}$ & $\begin{array}{c}2 \\
(\mathrm{n}=54)\end{array}$ & $\begin{array}{c}3 \\
(\mathrm{n}=38)\end{array}$ & $\begin{array}{c}\geq 4 \\
(\mathrm{n}=23)\end{array}$ & 1 vs. $\geq 2$ & 2 vs. $\geq 3$ & 3 vs. $\geq 4$ \\
\hline $\begin{array}{l}\text { Alcohol } \\
\text { Octan-1-ol } \\
\text { FFA }\end{array}$ & 4.43 & 4.64 & 4.31 & 4.45 & & 0.028 & \\
\hline $\begin{array}{l}\text { Butanoic acid } \\
\text { Heptanoic acid }\end{array}$ & $\begin{array}{r}12.50 \\
6.34\end{array}$ & $\begin{array}{r}12.40 \\
6.04\end{array}$ & $\begin{array}{r}12.35 \\
6.59\end{array}$ & $\begin{array}{r}12.29 \\
6.34\end{array}$ & 0.016 & 0.026 & 0.015 \\
\hline
\end{tabular}


Table 8. Linear regression $\left(\operatorname{Regr}^{1}\right)$ with daily milk yield of the quantity of the volatile organic compounds (VOC) with a significant effect of milk yield

\begin{tabular}{lccc}
\hline & \multicolumn{3}{c}{ Milk yield } \\
\cline { 2 - 4 } Chemical \\
\cline { 2 - 4 } family/VOC & Regr/SD & Regr/RMSE & $P$-value \\
\hline Alcohol & 0.008 & 0.021 & 0.010 \\
$\quad$ Octan-1-ol & 0.015 & 0.057 & 0.016 \\
$\quad$ 2-Phenylethanol & 0.024 & 0.068 & 0.011 \\
FFA & 0.021 & 0.035 & 0.019 \\
$\quad$ Pentanoic acid & & & \\
$\quad$ Heptanoic acid & -0.012 & -0.063 & 0.011 \\
$\quad$ Lactone &
\end{tabular}

${ }^{1}$ The interval unit of the regression coefficients calculated by dividing the regression coefficient of daily milk yield by the corresponding SD and root mean square error (RMSE).

aldehydes, as a family, were affected by milk productivity (Table 4), although none of the 4 individual aldehydes analyzed reached statistical significance. Only 5 of the other 51 individual VOC were affected by milk yield: 2 alcohols, 2 fatty acids, and dihydrofuran-2-(3H)-one (Table 8). In fact, the peak area values for octan-1-ol, 2-phenylethanol, pentanoic acid, and heptanoic acid increased with increasing milk yield, whereas that of dihydrofuran-2-(3H)-one decreased.

None of these VOC, with the exception of octan-1-ol, was contemporaneously affected by lactation stage. Because lactation stage has a strong effect on milk yield, which increases at the very beginning of lactation, peaks during the second month of lactation, and then declines during its final stages, the 2 effects are sometimes confused and often, in the literature, only the former is included in the statistical models. To fully understand the results, it should be borne in mind that as we estimated each effect, we kept the other effects constant. With respect to octan-1-ol, a concordance of sign was observed between the effects of milk yield and DIM, so that some overlap between the two cannot be excluded. Again, the literature offers little information and more research is needed on this topic.

\section{CONCLUSIONS}

The results of the present study provide a better understanding of the relationships between dairy farming system and individual cow characteristics and volatile compound composition of ripened cheese. This is especially important in mountain territories where the abandonment of traditional farming may be responsible for modification of the sensory properties of typical traditional cheeses. The results of our study also allowed us to evaluate the differences in the VOC profiles of different modern dairy systems and, in particular, the use of TMR, with or without silage, and with or without the addition of water to the resulting ration. Model cheeses made from milk produced by individual cows proved to be an effective method for studying sources of variation in the volatile organic profile as a function of individual traits of the animals and dairy farming systems. The use of the SPME/GC-MS allowed several volatile organic compounds to be determined: 55 VOC were detected in the model cheeses, including 14 alcohols, 13 esters, 11 free fatty acids, 8 ketones, 4 aldehydes, 3 lactones, 1 terpene, and 1 pyrazine. Dairy system, DIM, parity, and milk yield of Brown Swiss cows affected the VOC profiles of individual model cheeses. These findings could be useful in differentiating a given cheese from other products on the market by its VOC profile, to increase the economic value of milk, and to define traceability parameters based on sensory characteristics. Methodological sources of variation (vat, date of analysis, and order of injection) were often not significant, confirming good reproducibility of the cheesemaking procedure and instrumental analysis. To the best of our knowledge, the present study is the first to attempt to explain variation in the VOC profiles of cheeses produced from milk of individual cows.

\section{ACKNOWLEDGMENTS}

The authors thank the Autonomous Province of Trento (Trento, Italy) for funding the project Cowplus and the FEM "Accordo di Programma 2012/2014." The authors also acknowledge Ilario Bazzoli (Breeders Federation of Trento, Trento, Italy) for organizing the herd sampling and Elisa Forato (DAFNAE Department, University of Padova, Legnaro, Italy) for the SPME/ GC-MS analysis.

\section{REFERENCES}

Acree, T., and A. Arn. 2004. Flavornet and human odour space. Accessed Jan. 15, 2014. http://www.flavornet.org.

Aprea, E., M. L. Corollaro, E. Betta, I. Endrizzi, M. L. Dematte, F. Biasioli, and F. Gasperi. 2012. Sensory and instrumental profiling of 18 apple cultivars to investigate the relation between perceived quality and odour and flavour. Food Res. Int. 49:677-686.

Auldist, M. J., S. Coats, B. J. Sutherland, J. J. Mayes, G. H. McDowell, and G. Rogers. 1996. Effects of somatic cell count and stage of lactation on raw milk composition and the yield and quality of Cheddar cheese. J. Dairy Res. 63:269-280.

Barbano, D. M., and J. M. Lynch. 2006. Major advances in testing of dairy products: Milk component and dairy product attribute testing. J. Dairy Sci. 89:1189-1194.

Barbieri, G., L. Bolzoni, M. Careri, A. Mangia, G. Parolari, S. Spagnoli, and R. Virgili. 1994. Study of the volatile fraction of Parmesan cheese. J. Agric. Food Chem. 42:1170-1176.

Bellesia, F., A. Pinetti, U. Pagnoni, R. Rinaldi, C. Zucchi, L. Caglioti, and G. Palyi. 2003. Volatile components of Grana ParmigianoReggiano type hard cheese. Food Chem. 83:55-61.

Bendall, J. G. 2001. Aroma compounds of fresh milk from New Zealand cows fed different diets. J. Agric. Food Chem. 49:4825-4832. 
Berard, J., F. Bianchi, M. Careri, A. Chatel, A. Mangia, and M. Musci. 2007. Characterization of the volatile fraction and of free fatty acids of "Fontina Valle d'Aosta", a protected designation of origin Italian cheese. Food Chem. 105:293-300.

Bertoni, G., L. Calamari, M. G. Maianti, and B. Battistotti. 2005. Milk for Protected Denomination of Origin (PDO) cheeses: I. The main required features. Pages 217-228 in Indicators of Milk and Beef Quality. J. F. Hocquette and S. Gigli ed. EAAP Publication 112. Wageningen Academic Publishers, Wageningen, the Netherlands.

Bittante, G., A. Cecchinato, N. Cologna, M. Penasa, F. Tiezzi, and M. De Marchi. 2011a. Factors affecting the incidence of first-quality wheels of Trentingrana cheese. J. Dairy Sci. 94:3700-3707.

Bittante, G., C. Cipolat-Gotet, and A. Cecchinato. 2013. Genetic parameters of different measures of cheese yield and milk nutrient recovery from an individual model cheese-manufacturing process. J. Dairy Sci. 96:7966-7979.

Bittante, G., N. Cologna, A. Cecchinato, M. De Marchi, M. Penasa, F. Tiezzi, I. Endrizzi, and F. Gasperi. 2011b. Monitoring of sensory attributes used in the quality payment system of Trentingrana cheese. J. Dairy Sci. 94:5699-5709.

Bittante, G., A. Ferragina, C. Cipolat-Gotet, and A. Cecchinato. 2014. Comparison between genetic parameters of cheese yield and nutrient recovery or whey loss traits measured from individual model cheese-making methods or predicted from unprocessed bovine milk samples using Fourier-transform infrared spectroscopy. J. Dairy Sci. 97:6560-6572.

Bittante, G., M. Penasa, and A. Cecchinato. 2012. Invited review: Genetics and modeling of milk coagulation properties. J. Dairy Sci. 95:6843-6870.

Bovolenta, S., M. Corazzin, E. Saccà, F. Gasperi, F. Biasioli, and W. Ventura. 2009. Performance and cheese quality of Brown cows grazing on mountain pastures fed two different levels of supplementation. Livest. Sci. 124:58-65.

Bovolenta, S., A. Romanzin, M. Corazzin, M. Spanghero, E. Aprea, F. Gasperi, and E. Piasentier. 2014. Volatile compounds and sensory properties of Montasio cheese made from the milk of Simmental cows grazing on alpine pastures. J. Dairy Sci. 97:7373-7385.

Calamari, L., G. Bertoni, M. G. Maianti, and B. Battistotti. 2005. Milk for Protected Denomination of Origin (PDO) cheeses: II. The evaluation techniques of milk suitability. Pages 229-244 in Indicators of Milk and Beef Quality. J. F. Hocquette and S. Gigli ed. EAAP Publication 112. Wageningen Academic Publishers, Wageningen, the Netherlands.

Carbonell, M., M. Nunez, and E. Fernandez-Garcıa. 2002. Seasonal variation of volatile compounds in ewes raw milk La Serena cheese. Lait 82:699-711.

Cecchinato, A., A. Albera, C. Cipolat-Gotet, A. Ferragina, and G. Bittante. 2015. Genetic parameters of cheese yield and nutrient recovery or whey loss traits predicted using Fourier-transform infrared spectroscopy (FTIR) of samples collected during milk recording on Holstein, Brown Swiss and Simmental dairy cows. J. Dairy Sci. http://dx.doi.org/10.3168/jds.2014-8599.

Cecchinato, A., C. Cipolat-Gotet, J. Casellas, M. Penasa, A. Rossoni, and G. Bittante. 2013. Genetic analysis of rennet coagulation time, curd-firming rate, and curd firmness assessed over an extended testing period using mechanical and near-infrared instruments. J. Dairy Sci. 96:50-62.

Cipolat-Gotet, C., A. Cecchinato, M. De Marchi, and G. Bittante. 2013. Factors affecting variation of different measures of cheese yield and milk nutrient recovery from an individual model cheesemanufacturing process. J. Dairy Sci. 96:7952-7965.

Cipolat-Gotet, C., A. Cecchinato, M. De Marchi, M. Penasa, and G. Bittante. 2012. Comparison between mechanical and near-infrared methods for assessing coagulation properties of bovine milk. J. Dairy Sci. 95:6806-6819.

Coppa, M., I. Verdier-Metz, A. Ferlay, P. Pradel, R. Didienne, A. Farruggia, M. C. Montel, and B. Martin. 2011. Effect of different grazing systems on upland pastures compared with hay diet on cheese sensory properties evaluated at different ripening times. Int. Dairy J. 21:815-822.
Cornu, A., N. Rabiau, N. Kondjoyan, I. Verdier-Metz, P. Pradel, P. Tournayre, J. L. Berdagué, and B. Martin. 2009. Odour-active compound profiles in Cantal-type cheese: Effect of cow diet, milk pasteurization and cheese ripening. Int. Dairy J. 19:588-594.

Coulon, J. B., A. Delacroix-Buchet, B. Martin, and A. Pirisi. 2004 Relationships between ruminant management and sensory characteristics of cheeses: A review. Lait 84:221-241.

Curioni, P. M. G., and J. O. Bosset. 2002. Key odorants in various cheese types as determined by gas chromatography-olfactometry. Int. Dairy J. 12:959-984.

Drake, M. A. 2007. Invited review: Sensory analysis of dairy foods. J. Dairy Sci. 90:4925-4937.

Drake, M. A., R. E. Miracle, and D. J. McMahon. 2010. Impact of fat reduction on flavor and flavor chemistry of Cheddar cheeses. J. Dairy Sci. 93:5069-5081.

Endrizzi, I., E. Aprea, F. Biasioli, M. L. Corollaro, M. L. Demattè, M. Penasa, and G. Bittante. 2013. Implementing sensory analysis principles in the quality control of PDO products: A critical evaluation of a real-world case study. J. Sens. Stud. 28:14-24.

Endrizzi, I., A. Fabris, F. Biasioli, E. Aprea, E. Franciosi, E. Poznanski, A. Cavazza, and F. Gasperi. 2012. The effect of milk collection and storage conditions on the final quality of Trentingrana cheese: Sensory and instrumental evaluation. Int. Dairy J. 23:105-114.

Engels, W. J. M., R. Dekker, C. de Jong, R. Neeter, and S. A. Visser. 1997. A comparative study of volatile compounds in the water soluble fraction of various types of ripened cheese. Int. Dairy J. $7: 255-263$

Farruggia, A., D. Pomiès, M. Coppa, A. Ferlay, I. Verdier-Metz, A. Le Morvan, A. Bethier, F. Pompanon, O. Troquier, and B. Martin. 2014. Animal performances, pasture biodiversity and dairy product quality: How it works in contrasted mountain grazing systems. Agric. Ecosyst. Environ. 185:231-244.

Ferragina, A., C. Cipolat-Gotet, A. Cecchinato, and G. Bittante. 2013. The use of Fourier-transform infrared spectroscopy to predict cheese yield and nutrient recovery or whey loss traits from unprocessed bovine milk samples. J. Dairy Sci. 96:7980-7990.

Fox, P. F., P. L. H. McSweeney, T. M. Cogan, and T. P. Guinee. 2004. Cheese: Chemistry, Physics and Microbiology. Vol. 1. General Aspects. 3rd ed. Elsevier/Academic Press, London, UK.

Izco, J. M., and P. Torre. 2000. Characterisation of volatile flavour compounds in Roncal cheese extracted by the purge and trap method and analysed by GC-MS. Food Chem. 70:409-417.

Kalač, P. 2011. The effects of silage feeding on some sensory and health attributes of cow's milk: A review. Food Chem. 125:307-317.

Le Berre, E., N. Béno, A. Ishii, C. Chabanet, P. Etiévant, and T. Thomas-Danguin. 2008. Perceptual processing strategy and exposure influence the perception of odor mixtures. Chem. Senses 33:193-199.

Le Quéré, J. L. 2011. Cheese | Cheese Flavor. Pages 675-684 in Encyclopedia of Dairy Sciences. 2nd ed. J. W. Fuquay, P. F. Fox, P. L. H. McSweeney, ed. Academic Press, San Diego, CA.

Liaw, I., H. Eshpari, P. S. Tong, and M. A. Drake. 2010. The impact of antioxidant addition on flavor of Cheddar and Mozzarella whey and Cheddar whey protein concentrate. J. Food Sci. 75:C559-569.

Liggett, R. E., M. A. Drake, and J. F. Delwiche. 2008. Impact of flavor attributes on consumer liking of Swiss cheese. J. Dairy Sci. 91:466-476.

Liu, S. Q., R. Holland, and V. L. Crow. 2004. Esters and their biosynthesis in fermented dairy products: A review. Int. Dairy J. 14:923-945.

Lucas, A., C. Agabriel, B. Martin, A. Ferlay, I. Verdier-Metz, J. B. Coulon, and E. Rock. 2006. Relationships between the conditions of cow's milk production and the contents of components of nutritional interest in raw milk farmhouse cheese. Lait 86:177-202.

Mallia, S., E. Fernandez Garcia, and J. O. Bosset. 2005. Comparison of purge and trap and solid phase microextraction techniques for studying the volatile aroma compounds of three European PDO hard cheeses. Int. Dairy J. 15:741-758.

Marilley, L., and M. G. Casey. 2004. Flavours of cheese products: Metabolic pathways, analytical tools and identification of producing strains. Int. J. Food Microbiol. 90:139-159. 
Martin, B., I. Verdier-Metz, S. Hulin, A. Ferlay, P. Pradel, and J. B. Coulon. 2004. Combined influence of cow diet and pasteurization of the milk on sensory properties of French PDO Cantal cheese. Page 5 in Proc. 6th Int. Mtg. on Mountain Cheese, Cheese Art. CoRFILaC, Ragusa, Italy.

McSweeney, P. L. H., and M. J. Sousa. 2000. Biochemical pathways for the production of flavor compounds in cheeses during ripening: A review. Lait 80:293-324.

Padilla, B., C. Belloch, J. J. López-Díez, M. Flores, and P. Manzanares. 2014. Potential impact of dairy yeasts on the typical flavour of traditional ewes' and goats' cheeses. Int. Dairy J. 35:122-129.

Romanzin, A., M. Corazzin, E. Piasentier, and S. Bovolenta. 2013. Effect of rearing system (mountain pasture vs. indoor) of Simmental cows on milk composition and Montasio cheese characteristics. J. Dairy Res. 80:390-399.

Rychlik, M., and J. O. Bosset. 2001. Flavour and off-flavor compounds of Swiss Gruyere cheese. Identification of key odorants by quantitative instrumental and sensory studies. Int. Dairy J. 11:903-910.

San Román, I., M. L. Alonso, L. Bartolome, R. M. Alonso, and R. Faňanás. 2014. Analytical strategies based on multiple headspace extraction for the quantitative analysis of aroma components in mushrooms. Talanta 123:207-217.

Stefanon, B., and G. Procida. 2004. Effects of including silage in the diet on volatile compound profiles in Montasio cheese and their modification during ripening. J. Dairy Res. 71:58-65.

Sturaro, E., G. Cocca, L. Gallo, M. Mrad, and M. Ramanzin. 2009. Livestock systems and farming styles in Eastern Italian Alps: An on-farm survey. Ital. J. Anim. Sci. 8:541-554.

Sturaro, E., E. Marchiori, G. Cocca, M. Penasa, M. Ramanzin, and G. Bittante. 2013. Dairy systems in mountainous areas: Farm animal biodiversity, milk production and destination, and land use. Livest. Sci. 158:157-168.
Thomsen, M., C. Martin, F. Mercier, P. Tournayre, J. L. Berdagué, T. Thomas-Danguin, and E. Guichard. 2012. Investigating semihard cheese aroma: Relationship between sensory profiles and gas chromatography-olfactometry data. Int. Dairy J. 26:41-49.

Tornambé, G., A. Lucas, I. Verdier-Metz, S. Hulin, C. Agabriel, and B. Martin. 2005. Effect of production systems on sensory characteristics of PDO Cantal cheese. Ital. J. Anim. Sci. 4(Suppl. 2):248-250.

Toso, B., G. Procida, and B. Stefanon. 2002. Determination of volatile compounds in cows' milk using headspace GC-MS. J. Dairy Res. 69:569-577.

Tunick, M. H., S. K. Iandola, and D. L. Van Hekken. 2013. Comparison of SPME methods for determining volatile compounds in milk, cheese, and whey powder. Foods 2:534-543. http://dx.doi org/10.3390/foods2040534.

Urbach, G. 1995. Contribution of lactic acid bacteria to flavour compound formation in dairy products. Int. Dairy J. 5:877-903.

Urgeghe, P. P., C. Piga, M. Addis, R. Di Salvo, G. Piredda, M. F. Scintu, I. V. Wolf, and G. Sanna. 2012. SPME/GC-MS characterization of the volatile fraction of an Italian PDO sheep cheese to prevalent lypolitic ripening: The case of Fiore Sardo. Food Anal. Methods. 5:723-730

Verdier-Metz, I., B. Martin, P. Pradel, H. Albouy, S. Hulin, M. C. Montel, and J. B. Coulon. 2005. Effect of grass-silage vs. hay diet on the characteristics of cheese: Interactions with the cheese model. Lait 85:469-480.

Ziino, M., C. Condurso, V. Romeo, D. Giuffrida, and A. Verzera. 2005. Characterization of "Provola dei Nebrodi", a typical Sicilian cheese, by volatiles analysis using SPME-GC/MS. Int. Dairy J. 15:585-593. 